\title{
CERTAIN ASSESSMENTS RELATED TO THE RIGHT OF SUPERFICIES IN THE NEW ROMANIAN CIVIL CODE
}

\author{
I. Bratiloveanu*
}

\section{Izabela Bratiloveanu}

Faculty of Law and Administrative Sciences, University of Craiova, Craiova, Romania *Correspondence: Bratiloveanu Izabela, Craiova, 8 Horia St., B1. E2, sc. 2, ap.2 E-mail: bratiloveanuisabela@yahoo.com

\begin{abstract}
In this paper, we analyze the right of superficies as a significant new element of the actual Romanian Civil Code as compared to the provisions of the 1864 Romanian Civil Code, expressly regulated for the first time in Romanian legislation, in the first chapter of the $3^{\text {rd }}$ Title of the $3^{\text {rd }}$ Book, the articles from 693 to 702.
\end{abstract}

Key words: the new Civil Code; the right of superficies.

\section{Introduction}

The right of superficies has been acknowledged ever since the Roman legal system, as the right of a constructor to indefinitely use a building that had been erected on someone else's land, in exchange for a yearly amount of money (solarium) ${ }^{1}$. Being taken over in the modern civil right, following various hesitations and doctrinarian disagreements regarding its very existence, ever since the inter-war period we have witnessed the appearance of the constantly reiterated opinion according to which the right of superficies is an indirect consequence of the provisions of the article number 492 in the prior Civil Code (at present art. number 577 of the Civil Code $e^{2}$ ), as an exception to the rule of the artificial realty accession.

Until the actual Civil Code became recently effective, its legal status has been established by doctrine and jurisprudence.

\section{Definition and legal characteristics of the right of superficies}

Article no. 693 (1) of the Civil Code gives the following definition of the right of superficies: "The right of superficies is the right to own or erect a building on someone else's land, above or below that land, over which the builder acquires a right to use". We can therefore notice that, according to current regulations, within the legal content of that particular part of the right of superficies representing parts of the ownership right over the

\footnotetext{
* Ph.D. Candidate, Faculty of Law and Administrative Sciences, University of Craiova. This work was financed from the contract POSDRU/CPP107/DMI1.5/S/78421, strategic project ID78421 (2010), funded by the European Social Fund- "Invest in people", the Operational Program Human Resources Development 2007-2013. bratiloveanuisabela@yahoo.com

${ }^{1}$ For further details regarding the right of superficies in the Roman legal system, see E. Molcut, D. Oancea, Drept roman, "Şansa" S.R.L.Publishing House, Bucharest, 1993, p.131.

${ }^{2}$ Para. 1 in Art. no. 577 Civil Code side title "Work acquisition by the owner of the building" stipulates: "The constructions, plantations and any other works on a certain building thereafter called works, become the property of the building's owner, unless otherwise provisioned by law or legal documents".
} 
land, only the attribute of use is regulated expressis verbis. In the case of the right of superficies, we find ourselves faced with two overlapping ownership rights, belonging to two different owners: the builder's right - ownership of the buildings, plantations, works - and the land owner's right to land ownership. ${ }^{3}$

In the silence of the old Civil Code, the resolutions regarding the nature and legal contents of the right of superficies have not been similar. The old Romanian doctrine (C. Hamangiu, I. Rosetti-Bălănescu and Al. Băicoianu) has supported the idea that the right of superficies could be a special form of ownership, limited to the constructions or plantations on a land fund ${ }^{4}$. Recently, an idea has been expressed according to which only the builder's use right over a land which is someone else's property represents the actual right of superficies, and the legal complex resulting from the ownership right over the constructions, plantations and other works and the use right represent a mere variation of the ownership right, property which only consists of the existing constructions or plantations ${ }^{5}$. According to another perspective, to which we tend to subscribe, the right of superficies is the main realty right which combines, within its legal contents, the ownership right of a construction or plantation, with a main real right over a land belonging to someone else other than the holder of the superficies right, reuniting, in a limited way, use, possession and disposal over the land or part of it $^{6}$.

What is new in the view of the Civil Code is that the right of superficies is temporary; it can be set over a period of 99 years maximum, and it can be renewed once the set period has ended (art. 694 of the Civil Code). Until the present code has become effective, specialized literature and practice have credited the opposite opinion, according to which the right of superficies is perpetual by nature and lasts, unless otherwise stipulated, as much as the construction or the work on someone else's land, without there being any possibility of cancellation by lack of use. Therefore, not using the construction does not lead to the loss of the right of superficies ${ }^{7}$. Due to its temporary character, the right of superficies only acts as a suspension of the artificial realty accession right, not as its definitive removal. Consequently, once the time limit has expired, unless otherwise stipulated, the mechanism of the artificial realty accession becomes effective and, according to art. 699 (1) of the Civil Code "the landowner acquires the ownership right over the construction", while obligated to pay to the builder the current value of the construction. The second paragraph of article 696 in the Civil Code uncompromisingly stipulates the fact that the right to the admittance of the right of superficies cannot be prescribed, the relevant argument used in favour of this solution being the fact that the perpetual character of the ownership right over the construction, plantations and autonomous, enduring works also extends over that part of the superficies right which is related to the right over the land.

\footnotetext{
${ }^{3}$ See, as an example, C. Stătescu, Drept civil. Persoana fizică. Persoana juridică. Drepturile reale, Didactică şi Pedagogică Publishing House, 1970, p. 823.

${ }^{4}$ C. Hamangiu, I. Rosetti-Bălănescu, Al. Boicoianu, Tratat de drept civil, vol.2, C.H. Beck Publishing House, 2002, p.312.

${ }^{5}$ L. Pop, L.M. Harosa, Drept civil. Drepturile reale principale, UJ, 2006, p.257. In an opposite direction, legal practice has led to the conclusion that by acknowledging the right of superficies over the land and not the use right, the first instance was wrong regarding the complex contents of this right: besides the ownership right over the construction, it also always involves the use right over the land on which it is located (Brăila Courthouse, Civil section, Civil decision no. 180/2005)

${ }^{6}$ V. Stoica, Drept civil. Drepturile reale principale, Ed. C.H. Beck, 2009, p.238. Also see S. Cercel, "Dreptul de superficie", in Noul Cod Civil.Comentariu pe articole, coord. F.A. Baias, E. Chelaru, R. Constantinovici, I. Macovei, ed. CH Beck, 2012, p.748 and M. Uliescu, A. Gherghe, Drept civil. Drepturile reale principale, Ed. U.J., 2011, p. 140. For a thorough analysis of the various solutions stipulated in the French legal doctrine and of the arguments in favour of each viewpoint, see J.L. Bergel, M. Bruschi, S. Cimamonti, Les biens, L.G.D.J., 2010 , p. 331.

${ }^{7}$ See decision no. 649/1999 of the Appeal Court in Iaşi, Civil Section.
} 


\section{Means of instating the right of superficies}

Most frequently, within the legal practice a problem has arisen regarding the ways in which the right of superficies can be instituted, the resulting ideas being inserted as a whole in the current Civil Code, which, in art. 693 (2) stipulates the fact that the right of superficies is acquired by a legal document, by usucaption and otherwise provisioned by law. This enumeration is limitative, since, as already shown, the mere fact of erecting a construction on someone else's land, however honest-minded that person might be, and under the circumstances of the builder being fully aware of the fact that the latter is the owner of the land on which the new construction is located, would not be enough to lead to the acknowledgement of the existence of a right of superficies in favour of the person who erects a construction on a land that is not their own, and since there is no possibility of applying either one of the instatement methods mentioned above, the holder of the ownership right over the constructions can only acquire a mere claim against the holder of the ownership right over the land ${ }^{8}$. Therefore, in the absence of any legal foundation, the right of superficies cannot be acquired by means of a court rule ${ }^{9}$.

The right of superficies can be acquired by a legal act by onerous title or free of charge, authenticated under penalty of absolute invalidity (art. 1244 of the Civil Code). In the case of conventions, there are two possible situations: $i$ ) the landowner reserves their empty property and grants the right of superficies to the other contracting party, ii) the landowner keeps the right of superficies and grants the empty property. If the builder obtains an agreement from the holder of the ownership right over the land, he acquires a right of superficies, any lack of a building authorization being completely irrelevant. ${ }^{10}$ In full agreement with the legal practice ${ }^{11}$, the last paragraph of art. 693 in the Civil Code was inserted, stipulating the fact that the right of superficies can be turned in the builder's favour on account of the holder of the ownership right over the land resigning their right to claim accession, and in a third party's favour on account of the owner resigning the right to claim accession. It has also been decided that, within family relationships, when parents normally allow their children to have a building erected on the land which is their property, a certificate is morally impossible to draft ${ }^{12}$. The right of superficies can also be certified on account of a legal document, under the provisions of art. 693 (3), when the owner of the entire fund (both land and construction) sold either the construction alone, or the land and the construction as well, but to different people, in which case the right of superficies can be registered in the cadastral register even if there has been no express mention of the instatement of the right of superficies in the construction estrangement act. Furthermore, the legal practice has agreed to

\footnotetext{
${ }^{8}$ In this view, see the Civil Decision no. 1394/2010 of the Bârlad Courthouse, the Civil Decision no. 6529/2010 of the Bihor County Courthouse, the Decision no. 868/2011 of the Civil Section at the Appeal Court in Braşov, the Civil Sentence no. 8938/2009 of the Iaşi Court of Justice, all available at http://portal.just.ro, the Civil Decision no. 11057/1997 of the Argeş Courthouse, Culegere de practică judiciară 1998, ed. All Beck, 1999, the Civil Decision no. 457/2009 of the Appeal Court in Timişoara, and the www.jurindex.ro website, as viewed on the $4^{\text {th }}$ of December 2012.

${ }^{9}$ Case law solution: the Civil Decision no. 1406/2009 of the Videle Courthouse, available at http://portal.just.ro, as viewed on the $4^{\text {th }}$ of December 2012.

${ }^{10}$ See the Decision no. 4559/2005 of the Civil and copyright section at the Romanian High Court of Cassation and Justice.

${ }^{11}$ The Civil Decision no. 43/2007 of the Civil section at the Appeal Court in Bucharest, available at http://portal.just.ro. In this case, it has been decided that the landowner's inaction or acceptance equals their consent to erect the construction, thus enabling the instatement of a right of superficies in favour of the constructor. Also see the Romanian High Court of Cassation and Justice, Civil and copyright section, available at www.legalis.ro., as viewed on the $4^{\text {th }}$ of December 2012.

${ }^{12}$ In this regard, see the Civil Decision no. 195/2011 of the Constanța Courthouse, and the Civil Decision no. $2510 / 2011$ of the Caracal Courthouse, both available at http://portal.just.ro, as viewed on the $4^{\text {th }}$ of December 2012.
} 
this solution, by adopting a firm position in the sense that "even if there has been no convention between the landowner and the construction owner, by means of which the latter gives their consent to having their land encumbered, it can be admitted, on account of a rational interpretation of art. 492 of the Civil Code that, by acquiring an ownership right over the construction, a right of superficies is generated ope legis for its owner" ${ }^{\prime 3}$. The right of superficies can be acquired by legacy, when the testator assigns a person who, at the moment of the former's death, will acquire either empty property or the right of superficies, or when two different heirs are assigned, one of whom will acquire empty property and the other will acquire the right of superficies over a construction, plantation or any other durable works.

The current Civil Code also regulates the way to acquire the right of superficies by adverse possession, when the land holder acts as a person who has a right of superficies, not as the landowner; we will however not enlarge upon this topic, since it is seldom put into practice $^{14}$.

The right of superficies can also be acquired by "other means, as provisioned by law", for example, in the case of applying the legal or the conventional community system ${ }^{15}$, by the particular spouse having a construction, a plantation or any other autonomous, durable work erected on the other spouse's land; the spouse who is not the landowner acquires a use right over their spouse's land and shared ownership right over the construction, plantation or work $^{16}$.

\section{Extension and exercise of the right of superficies}

According to article 695 of the Civil Code, the right of superficies is exercised within the limits and conditions of its constitution document. According to the case law ${ }^{17}$, current regulations mention that, unless otherwise stipulated, the exercise of the right of superficies is limited by the surface of the land on which the construction is to be erected and by the surface which is necessary to the use of that construction or the corresponding land and the surface which is necessary to the use of that construction.

\section{Cessation of the right of superficies}

The new Civil Code minutely regulates all instances of cessation of the right of superficies and their specific effects. According to the provisions of article number 698 in the Civil Code, the right of superficies can cease in one of these ways: $a$ ) when the time period expires, $b$ ) by consolidation, $c$ ) when the construction is demolished, if specifically stipulated and $d$ ) in other cases, as provisioned by law. The fact that the holder of the ownership right over the land sells the land which has been the object of the right of superficies cannot lead to the cessation of this right ${ }^{18}$. It has to be said that the right of superficies only ceases once it has been erased from the land registry book (art. 885 of the Civil Code).

The right of superficies ceases once the time period in its constitution document has expired or, should the time period not be mentioned in that respective document, at the end of the 99-year period, should the right of superficies not be renewed thereafter. In the

\footnotetext{
${ }^{13}$ Decision no. 214/2010 of the Civil Section of the Appeal Court in Bucharest.

${ }^{14}$ See, as an example, the decision no. 379 of the $21^{\text {st }}$ of January 2005 of the Civil and copyright section of the Romanian High Court of Cassation and Justice.

15 According to the provisions of art. 339 Civil Code, "The assets that have been acquired during the legal communion by either one of the spouses become, from the date of their acquisition, shared assets of the spouses".

${ }^{16}$ In specialized works it has been rightfully shown that in this case the source of the right of superficies is the mere legal fact of the spouses having acquired a construction, a plantation or a work, placed on the land which belongs to one of them, in the course of their marriage, fact which legally generates this effect. For further details, see V. Stoica, cited work, p. 244.

${ }^{17}$ See the Civil Decision no. 219/2007 of the Appeal Court in Bucharest and the decision no. 1515/1973 of the Civil Section at the Supreme Court in the Romanian Decision Registry, no. 5/1973, p.73.

${ }^{18}$ In this sense, see the mercantile Decision no 496/2004 of the Mercantile Section of the Appeal Court in Iaşi.
} 
constitution document of the right of superficies or at any time thereafter, the parties can establish what is going to happen to the construction, plantation or work at the end of this time period. If not, the mechanism of artificial realty accession becomes effective and the landowner acquires the ownership right over the constructions, plantations or works which have in time been erected by the builder, while obligated to pay their current value to the builder once the time period has expired (art. 699 para. 1 of the Civil Code). An interesting, more nuanced solution mentioned at art. 699 (2) of the Civil Code is the one related to the case in which the construction was not erected at the time of the instatement of the right of superficies and its value equals or exceeds that of the land. In this case, the text stipulates the fact that the landowner has to choose between acquiring the ownership right over the construction, by means of the acquisition effect of the artificial realty accession, and determining the builder to purchase the land at the value at which it would have been estimated had the construction not been erected; in the latter case, the builder can refuse purchase if they erect the construction at their own expense and restore the land to its previous situation. Once the time period has expired, principal real rights agreed to by the holder of the right of superficies cease to be effective, should the owner not agree to their maintenance. As for the mortgages, we must $a b$ initio distinguish between those related to the right of superficies and those related to the land itself. At the cessation of the right of superficies, the Civil Code presents three distinctive cases regarding those mortgages related to the right of superficies: 1) the landowner also becomes the construction owner, in which case the mortgage is rightfully transferred to the amount of money the builder has received; 2) the builder purchases the land, in which case the mortgage rightfully extends over the land and 3) the builder refuses purchase and restores the land to its previous situation, and the mortgage is rightfully transferred to the material results of the construction demolition. As for the mortgages related to the land, once the time period has expired, in the three cases mentioned above, the Code establishes the following: in the first case, the mortgages are not extended to the entire building; in the second case, it is rightfully transferred to the amount of money the builder has received and, in the last case, it is rightfully extended to the entire land. The right of superficies ceases as a result of consolidation when the land and the construction become property of one and the same person. According to article number 700 of the Civil Code, unless otherwise stipulated, the main real rights agreed to by the holder of the right of superficies are maintained all throughout the time period over which they have been instated, but no later than the initial expiry date of the right of superficies, and the mortgages that have been taken on during the time the right of superficies was effective are all maintained according to the object of their constitution.

Art. 698 c) of the Civil Code determines the fact that the right of superficies ceases to exist if the construction is demolished, should there be any specific mention of this aspect. What is noticeable is that the text comes in contradiction with the jurisprudential and doctrinarian perspective according to which, should the work, plantation or construction have been demolished or totally annihilated by the builder, the building right ceases to exist ${ }^{19}$. The argument in favour of the current solution is that, in the legal contents of the right of superficies there still remains a main real right derived from the ownership of land. As an effect of the cessation of the right of superficies in this way, in the absence of a contrary legal provision, the real rights encumbering the right of superficies cease, and regarding the mortgages involving the empty ownership over the land until the expiry date of the right of superficies, the text of article 701 in the Civil Code stipulates that they are maintained and are related to the reinstated ownership over the land.

\footnotetext{
${ }^{19}$ See Chelaru, Drept civil. Drepturile reale principale, C.H. Beck Publishing House, 2009, p. 329, C. Bârsan, op. cit., p.300, the Decision no. 888/2008 of the Civil and copyright section of the Romanian High Court of Cassation and Justice.
} 


\section{Conclusions}

1.The right of superficies has also been recently mentioned in the French Civil Code, which, at article number 2531, introduced by the Decree no. 2005-870 of the $28^{\text {th }}$ of July 2005 , mentions this right among those which can be placed under mortgage. The solution that the Romanian legislator has chosen is different from the French one, and preferable, because within our legal system there is a uniform, minute regulation of the right of superficies.

2. Mostly, in this matter, for the first time, it gives legislative consecration to long existing jurisprudential rules, which have been largely accepted by doctrine.

\section{Bibliography}

Baias Flavius-Antoniu, Chelaru Eugen, Constantinovici Rodica, Macovei Ioan coordonatori, Noul Cod Civil. Comentariu pe articole, C.H. Beck Publishing House, Bucharest, 2012.

Terzea Viorel, Noul Cod Civil. Adnotat cu doctrină şi jurisprudenţă, Universul Juridic Publishing House, Bucharest, 2011;

Uliescu Marilena, Gherghe Aurelian, Drept civil.Drepturile reale principale, Universul Juridic Publishing House, Bucureşti, 2011;

Chelaru Eugen, Drept civil. Drepturile reale principale, C.H. Beck Publishing House, Bucharest, 2009;

Jora Cristian, Uță Lucia, Drept civil. Curs de drepturi reale, Lumina Lex Publishing House, Bucharest, 2009;

Stoica Valeriu, Drept civil. Drepturile reale principale, C.H. Beck Publishing House, Bucharest, 2009;

Zamşa Cristina, Drept civil. Drepturile reale principale. Manual de seminar, C.H. Beck Publishing House, Bucharest, 2009;

Pop Liviu, Harosa Liviu-Marius, Drept civil. Drepturile reale principale, Universul Juridic Publishing House, Bucharest, 2006;

Dogaru Ion, Cercel Sevastian, Drept civil. Teoria generală a drepturilor reale, All Beck Publishing House, Bucharest, 2003;

Hamangiu Constantin, Rosetti Bălănescu Ion, Băicoianu Alexandru, Tratat de drept civil, vol.2, C.H. Beck Publishing House, 2002; 